УДК: 378.37.004

DOI: $\underline{10.35619 / \text { iiu.v1i13.360 }}$

Собченко Тетяна

кандидат педагогічних наук, доцент, доцент кафедри освітології та інноваційної педагогіки

Харківського національного педагогічного

університету імені Г. С. Сковороди,

м. Харків, Україна

ORCID: 0000-0002-9213-5556

e-mail: sobchenkotetyana79@gmail.com

\title{
МЕТОДОЛОГІЧНІ ЗАСАДИ ДОСЛІДЖЕННЯ ПРОБЛЕМИ ЗДІЙСНЕННЯ ЗМІШАНОГО НАВЧАННЯ СТУДЕНТІВ-ФІЛОЛОГІВ
}

Анотація. Суттєві зміни, які відбуваються у системі вищої освіти, спрямовані на забезпечення іiі якості та доступності в Україні. Одним із шляхів вирішення проблеми $\epsilon$ впровадження технології змішаного навчання. Актуальність проблеми здійснення змішаного навчання майбутніх учителів-філологів зумовлена низкою факторів, серед яких вирішальними $\epsilon$ інформатизація та цифровізація усіх сфер життя, зокрема системи вищої освіти, а також світова пандемія, яка прискорила перехід на такий формат навчання усі заклади вищої освіти.

Метою статті $\epsilon$ висвітлення методологічних засад реалізації змішаного навчання майбутніх учителів-філологів у закладах вищої педагогічної освіти. У статті проаналізовано суть поняття «змішане навчання». Визначено та уточнено ті моделі змішаного навчання, які можуть бути застосовані у процесі вивчення педагогічних дисциплін майбутніми учителями-філологами. Проаналізовано особливості побудови моделі змішаного навчання та фактори, які слід враховувати при виборі чи створенні власної моделі. Розкрито дидактичні принципи змішаного навчання. Виділено та проаналізовано основні методологічні підходи реалізації змішаного навчання майбутніх учителів-філологів: системносинергетичний, особистісно-діяльнісний, компетентнісний, ресурсний, герменевтичний.

Ключові слова: методологічний підхід, здобувач, змішане навчання, освітній процес, принцип, модель.

Постановка проблеми. Інноваційна діяльність закладів вищої освіти пов'язана з активним упровадженням педагогічних технологій, серед яких чільне місце посідає змішане навчання. Стрімкий розвиток інформаційнокомунікативних технологій, дегіталізація усіх сфер діяльності людини, зокрема системи освіти, пандемія COVID-19, яка внесла суттєві зміни у освітній процес, стали передумовами впровадження змішаного навчання у

(C) Собченко Т., 2021 


\section{Інноватика у вихованні. Випуск 13.Том 1. 2021.}

заклади вищої освіти в Україні та за їі межами.

Змішане навчання, як інструмент модернізації сучасної освіти передбачає використання традиційних підходів організації навчання та інформаційно-комунікативних, мультимедійних, цифрових технологій. На необхідності активного впровадження затребуваних комп'ютерних освітніх технологій у роботу закладів вищої освіти й, зокрема, вищої педагогічної освіти наголошується в провідних нормативних документах, зокрема: закони України «Про освіту», «Про вищу освіту», «Про національну програму інформатизації», наказ Міністерства освіти і науки України «Про затвердження Положення про дистанційне навчання», «Про затвердження Вимог до вищих навчальних закладів та закладів післядипломної освіти, наукових, освітньо-наукових установ, що надають освітні послуги за дистанційною формою навчання 3 підготовки та підвищення кваліфікації фахівців за акредитованими напрямами i спеціальностями», Проєкт «Цифрової адженди - 2020», «Концепція розвитку цифрових компетентностей та затвердження плану заходів 3 iі реалізації», «Державна стратегія регіонального розвитку на 2021-2027 роки» тощо.

Змішане навчання регламентовано у таких документах Міністерства освіти і науки України: «Рекомендації щодо впровадження змішаного навчання у закладах фахової передвищої та вищої освіти» (2021), «Рекомендації щодо організації поточного, семестрового контролю та атестації здобувачів освіти із застосуванням дистанційних технологій» (2020).

Аналіз останніх досліджень 3 проблеми. Проблему використання змішаного навчання студіювали вітчизняні та зарубіжні вчені, а саме його теоретико-методичні аспекти: В. Бикова, Т. Бодненко, Н. Морзе, Н. Рашевська, С. Семеріков, О. Спірін, С. Смирнова-Трибульска, А. Стрюк, Ю. Триус, В. Фандій, А. Фоміна, Т. Шроль, К. Бонк, М. Хорн, Ч. Грехем, М. Грубер, Ч. Дзіюбан, Г. Маєр, А. Норберг, К. Спрін, Х. Стакер, Б. Хан, Д. Харісон та інші.

А. Кудін та О. Міненко розглядають питання практичної реалізації технологій змішаного навчання та пропонують навчально-методичну розробку -дидактична картка дисципліни (Кудін та Міненко, 2018).

В. Мар'єнко досліджує місце наукових платформ та хмарних сервісів у системі наукової освіти вчителя (Мар`єнко, 2019).

М. Іващенко, Т. Бикова розробили алгоритм упровадження елементів змішаного навчання в процес викладання навчальних дисциплін у закладах вищої освіти шляхом поєднання традиційної моделі навчання та інноваційної моделі електронного навчання (Іващенко та Бикова, 2018).

Теоретичні, методичні, практичні засади підготовки майбутніх учителів вивчали Г. Ткачук, О. Барна, О. Коротун (вчителів інформатики), Т. Бондаренко, Т. Свтухова (вчителів початкової школи), К. Осадча, В. Осадчий, В. Круглик, I. Наумук (професійної освіти), I. Малова, М. Москалюк, Н. Москалюк (методична підготовка майбутнього вчителя 3 


\section{Інноватика у вихованні. Випуск 13.Том 1. 2021.}

урахуванням сучасних освітніх технологій), М. Ячменник (підготовка майбутнього вчителя української мови та літератури).

Незважаючи на посилену увагу вчених до проблеми впровадження змішаного навчання у закладах освіти, однак залишаються недостатньо вивченими та обгрунтованими методологічні засади реалізації змішаного навчання майбутніх учителів-філологів.

Мета статті полягає у висвітленні методологічних засад реалізації змішаного навчання майбутніх учителів-філологів у закладах вищої педагогічної освіти.

Виклад основного матеріалу дослідження. Визначаючи суть поняття «змішане навчання», слід зазначити, що його розглядають як форму, модель, методику, процес, тощо. У виданих МОН «Рекомендаціях щодо впровадження змішаного навчання у закладах фахової передвищої та вищої освіти» зазначено, що змішане навчання - це безпосередня взаємодія між студентами та викладачами в аудиторії із використанням онлайнтехнологій (2021). Спільним для різних підходів розуміння суті змішаного навчання є те, що в його основі закладено взаємодію суб' єктів в освітньому процесі шляхом поєднання дистанційного навчання (онлайн) та традиційного навчання (офлайн).

Реалізація змішаного навчання передбачає використання широкого спектру засобів інформаційно-комунікативних технологій, хмарних сервісів, освітніх платформ, які є доступними для всіх учасників освітнього процесу. Це створює оптимальні умови для покращення інформаційноресурсного забезпечення для оволодінням змісту освіти у процесі навчання, розширення спектру навчальних засобів i педагогічних технологій, які можуть бути ефективно застосовані в навчально-виховному процесі (Богачков, 2012).

3 огляду на те, що змішане навчання має у наявності великий вибір засобів навчання, воно передбачає різні моделі його реалізації. На сьогоднішній день у педагогічній літературі існують різні моделі змішаного навчання від простих та популярних до складних та руйнівних. Серед широкого діапазону моделей змішаного навчання виділяють основні, які були запропоновані К. Бонком та Ч. Гремом у «Довіднику змішаного навчання: глобальні перспективи, зразки» (Бонк, Грем, 2006): Rotation Model» (Ротаційна модель); «Station Rotation Model» (Модель зміни станцій); «Lab Rotation Model)» (Модель зміни лабораторій); «Flipped Model» (Модель перевернутого навчання); «Individual Rotation Model» (Персоналізована модель); «Flex Model» (Гнучка модель); «SelfBlend Model» (Модель самостійного змішування); «Enriched Virtual Model» (Віртуально-збагачена модель).

Для педагогічних закладів вищої освіти, на нашу думку, слід використовувати такі моделі змішаного навчання на прикладі викладання педагогічних дисциплін («Основи педагогічної майстерності», «Теорія виховання», «Дидактика», «Історія педагогіки», «Порівняльна педагогіка», «Педагогіка нової української школи»): «Flipped Model» (Модель 


\section{Інноватика у вихованні. Випуск 13.Том 1. 2021.}

перевернутого навчання), «Rotation Model» (Ротаційна модель), «Lab Rotation Model» (Модель зміни лабораторій).

Для ефективної організації та впровадження змішаного навчання варто чітко обрати ту модель, яка буде ефективною та задовільнятиме запит та очікування викладача, який розроблятиме навчальну дисципліну.

$\mathrm{У}$ «Рекомендаціях щодо впровадження змішаного навчання у закладах фахової передвищої та вищої освіти» запропоновано поради щодо створення ефективної моделі змішаного навчання, складові якої мають чітко узгоджуватись між собою, зокрема цілі освітньої програми, очікувані програмні результати, види діяльності та оцінювання (2021). Але на сьогоднішній день відсутній чіткий алгоритм створення або вибору моделі змішаного навчання. Тому на основі аналізу наукової, психологопедагогічної літератури, власного досвіду організації змішаного навчання майбутніх учителів-філологів зазначимо такі особливості, які слід врахувати при виборі моделі змішаного навчання: курс навчання (освітньокваліфікаційний рівень здобувачів); місце навчальної дисципліни у навчальному плані; форму організації навчання (денна, заочна, дуальна); кількість годин (аудиторної, самостійної роботи); специфіку факультету (гуманітарний, технічний); мету, завдання, очікувані програмовані результати навчальної дисципліни; відповідність змісту; форму контролю навчально-пізнавальної діяльності (усний, письмовий, залік, іспит); матеріально-технічне оснащення та забезпечення (доступ до мережі Інтернет, устаткування, обладнання, їх кількість); рівень цифрової компетентності викладача та здобувачів вищої освіти, вміння володіти інформаційно-комунікативними технологіями; рівень навчальних досягнень студентів тощо (Собченко, 2021).

Вважаємо за доцільне виокремити такі дидактичні принципи успішної та ефективної реалізації змішаного навчання:

гуманістичності (організація сприятливих умов навчання, орієнтир на особистість здобувача як на найвищу цінність);

демократизації (рівний розподіл прав та обов'язків, повноважень та відповідальності);

активності та самостійності (активізація навчально-пізнавальної активності);

свідомості (свідоме ставлення до навчання та відповідальність за результат);

міцності засвоєння знань (доступний навчальний контент, який можна переглядати додатково за потреби);

наочності та інтерактивності (використання цифрових сервісів та платформ для створення інтерактивного контенту - онлайн, ілюстрація, демонстрація, спостереження - офлайн);

системності й послідовності (структурування та подача навчального матеріалу системно);

адаптивності та урахування індивідуальних особливостей (орієнтація на особисті та освітні потреби здобувачів); 
стимулювання і мотивації (позитивне ставлення до навчання);

гнучкості (вибір зручного темпу, місця, часу навчання).

Методологічні основи реалізації змішаного навчання майбутніх учителів-філологів складають такі основні методологічні підходи:

- системно-синергетичний підхід, що дозволяє досліджувати предмет дослідження та самих суб'єктів освітнього процесу в їх постійному розвитку як відкритих синергетичних систем;

- особистісно-діяльнісний підхід, що визначає унікальність кожної особистості та їі особистих інтересів, потреб та можливостей, а також провідну роль діяльності як провідного фактору формування здобувачів освіти як фахівців та як особистостей;

- компетентнісний підхід, який зорієнтований на забезпечення оволодіння здобувачами вищої педагогічної освіти загальними (насамперед цифровою компетентністю) та предметними компетентностями);

- ресурсний підхід, що дає можливість, з одного боку, враховувати матеріально-технічні, викладацькі, інформаційні, освітні, методичні ресурси закладу вищої освіти, а з іншого боку - фізіологічні, психічні, енергетичні, освітні ресурси здобувачів вищої освіти;

- герменевтичний підхід, що спрямовує кожного учасника взаємодії реалізувати осягнення тексту в широкому його значенні на трьох рівнях: усвідомлення образно-смислового змісту (граматичне та психологічне інтерпретування), історичне інтерпретування та створення цілісної виконавської концепції як відкритої системи, що передбачає організацію різних видів діалогів (здобувача з текстом, здобувача та його автора, здобувача й викладача, здобувача та культури в цілому).

Висновки і перспективи подальших розвідок. Висвітлюючи методологічні засади реалізації змішаного навчання майбутніх учителівфілологів у закладах вищої педагогічної освіти, нами з'ясовано, що в основі змішаного навчання лежить взаємодія суб'єктів в освітньому процесі шляхом поєднання дистанційного навчання (онлайн) та традиційного навчання (офлайн). Окреслено особливості побудови моделей змішаного навчання та дидактичні принципи.

Визначено, що методологічні основи реалізації змішаного навчання майбутніх учителів-філологів утворюють такі основні методологічні підходи: системно-синергетичний, особистісно-діяльнісний, компетентнісний, ресурсний, герменевтичний. Проведений науковий пошук не вичерпує усіх аспектів проблеми реалізації змішаного навчання майбутніх учителів-філологів у закладах вищої педагогічної освіти. Перспективами подальшого наукового пошуку є розробка та реалізація дидактичної системи змішаного навчання майбутніх учителів філологічних спеціальностей. 


\section{Інноватика у вихованні. Випуск 13.Том 1. 2021.}

\section{СПИСОК ВИКОРИСТАНИХ ДЖЕРЕЛ}

Богачков, Ю., Биков, В., Пінчук, О. та Манако, А. (2012). Організациія середовища дистаниійного навчання в середніх загальноосвітніх навчальних закладах: посібник. К.: Педагогічна думка. С.19.

Іващенко, М. та Бикова, Т. (2018). Особливості використання елементів змішаного навчання в процесі викладання навчальних дисциплін у закладах вищої освіти. Фізико-математична освіта. Випуск 1(15). СС. 221-226.

Кудін, А. та Міненко, О. (2018). Сценарії технології змішаного навчання математики в системі MOODLE. Фізико-математична освіта. Випуск 1(15). СС. 68-72.

Мар'єнко, М. (2019). Наукові платформи та хмарні сервіси, їх місце у системі наукової освіти вчителя. Фізико-математична освіта. Випуск 4 (22). CC. 93-99.

Міністерство освіти і науки України, (2021). Рекомендащиї щзодо впровадження змішаного навчання у закладах фахової передвищої та вищої освіти. URL: https://mon.gov.ua/storage/app/media/vishchaosvita/2020/zmyshene\%20navchanny/zmishanenavchannia-bookletspreads2.pdf. [Дата звернення 04.05.21].

Bonk, C. \& Graham, M (2006). The Handbook of Blended Learning: Global Perspectives, Local Designs / Bonk, C.R.G. Moore. Pfeiffer. 624 p.

Sobchenko, T. (2021). Choice of blended learning models for higher pedagogical education students.Physical andMathematical Education. Issue 2(28). P.17-21. URL: https://fmo-journal.org/index.php/fmo/issue/view/3 [Дата звернення 02.05.21].

\section{REFERENCES}

Bohachkov, Y., Bykov, V., Pinchuk O. \& Manako A. (2012) Orhanizatsiia seredovyshcha dystantsiinoho navchannia $v$ serednikh zahalnoosvitnikh navchalnykh zakladakh [Organization of distance learning environment in secondary schools]. K.: Pedahohichna dumka. S.19. [in Ukrainian].

Ivashchenko, M. \& Bykova, T. (2018) Naukovi platformy ta khmarni servisy, yikh mistse u systemi naukovoi osvity vchytelia [The Peculiarities Of Using the Elements Of Mixed Learning in the Process Of Teaching Academic Disciplines in Higher Education Institutions]. Fizyko-matematychna osvita. Vypusk 1(15). SS. 221-226. [in Ukrainian].

Kudin, A., Minenko, O. (2018) Stsenarii tekhnolohii zmishanoho navchannia matematyky $v$ systemi MOODLE [Scenario of Mixed Learning Technology of Mathematics in the MOODLE System]. 221-226. Fizykomatematychna osvita-1(15). SS. 68-72. [in Ukrainian].

Marenko, M. (2019) Naukovi platformy ta khmarni servisy, yikh mistse u systemi naukovoi osvity vchytelia [Scientific platforms and cloud services, their place in the system of scientific education of teachers]. Fizyko-matematychna osvita - 4(22). [in Ukrainian]. 
Ministerstvo osvity i nauky Ukrainy, (2021). Rekomendatsii shchodo vprovadzhennia zmishanoho navchannia u zakladakh fakhovoi peredvyshchoi ta vyshchoi osvity [Recommendations for the introduction of blended learning in institutions of professional higher and higher education]. URL: https://mon.gov.ua/storage/app/media/vishcha-osvita/2020/zmyshene\%20 navchanny/zmishanenavchannia-bookletspreads-2.pdf [Data zvernennia 4.05.21]. [in Ukrainian].

Bonk, C. \& Graham, M (2006) The Handbook of Blended Learning: Global Perspectives, Local Designs / Bonk, C.R.G. Moore. Pfeiffer. 624 p.

Sobchenko, T. (2021). Choice of blended learning models for higher pedagogical education students.Physical andMathematical Education. Issue 2(28). P.17-21. URL: https://fmo-journal.org/index.php/fmo/issue/view/3 [Data zvernennia 02.05.21].

\title{
METHODOLOGICAL BASIS FOR RESEARCHING THE PROBLEM OF IMPLEMENTATION OF BLENDED LEARNING OF STUDENTS PHILOLOGISTS
}

\author{
Tetiana Sobchenko \\ Ph.D. in Pedagogy, Associate Professor, Head at the Department \\ of Educology and Innovative Pedagogy \\ H.S. Skovoroda Kharkiv National Pedagogical University, \\ Kharkiv, Ukraine \\ ORCID: 0000-0002-9213-5556 \\ e-mail: sobchenkotetyana79@gmail.com
}

\begin{abstract}
The urgency of the problem of blended education of future Philology teachers is due to a number of factors, among which the decisive is the informatization and digitalization of all spheres of life, including higher education, and the global pandemic that has accelerate the transition to such higher education. The purpose of the article is to highlight the methodological principles of the implementation of blended learning of Philology teachers in institutions of higher pedagogical education. The article analyzes the essence of the concept "blended learning" and determines that it has been characterized by a combination of traditional approaches (offline) and distance (online) with extensive using of information and communication, computer and digital technologies. It has been identified the definded models of blended learning that can be used in the study of pedagogical disciplines by Philology teachers. The peculiarities of creating a model of blended learning and the factors that should be taken into account when choosing or creating your own model has been analyzed. Didactic principles of blended learning were reveal. The main methodological approaches to the implementation of blended learning of future Philology teachers have been highlighted and analyzed: system-synergetic (explains the problem of development and implementation of blended learning in the form of pedagogical system as a complex nonlinear formation developing
\end{abstract}




\section{Інноватика у вихованні. Випуск 13.Том 1. 2021.}

from chaos, because the development of educational processes corresponds to synergetic characteristics). self-activity (determines the uniqueness of each individual and his personal interests, needs and capabilities, as well as the leading role of activity as a leading factor in the formation of students as professionals and as individuals), competence (its research potential is particular importance for research provides an opportunity to coordinate the educational process and gain knowledge about the organization of blended learning in higher pedagogical education), resource (provides for the identification and involvement of external influence resources that can ensure the effectiveness of activities to intensify internal resources of pre-service teachers of philology, their ability to self-development and self-organization), hermeneutic (improves the educational process in IHPE and promotes active creative self-development, successful self-realization of all its participants).

Keywords: methodological approach, applicant, blended learning, educational process, principle, model.

Стаття надійшла до редакиії 07.05.2021p. 